\title{
KONTRIBUSI TEORI ILMIAH TERHADAP PENAFSIRAN
}

\author{
Ali Akbar \\ Fakultas Ushuluddin UIN Sultan Syarif Kasim Riau \\ aliakbarusman@yahoo.co.id
}

\begin{abstract}
Abstrak
Penafsiran terhadap ayat al-Qur'an tidak akan pernah berakhir, sesuai dengan perkembangan zaman dan ilmu pengetahuan. Munculnya tafsir 'ilmy dalam khazanah inteleklual Islam merupakan respons supaya ajaran yang terdapat dalam al-Qur'an tetap relevan dengan realitas atau fenomena-fenomena yang terjadi dan perkembangan zaman. Selain itu, tafsir 'ilmy juga berupaya memperbaiki pengetahuan seseorang yang telah ada dan membuka tabir makna ayat-ayat al-Qur'an tertentu yang belum mampu dipahami oleh umat sebelumnya secara ilmiah. Adanya tiori-tiori ilmiah ini akan menghasilkan penemuan-penemuan baru sesuai dengan pesan-pesan Allah SWT dalam al-Qur'an. Di samping juga akan menunjukkan sifat fleksibilitasnya al-Qur'an yang dipandang pantas, cocok dan sesuai untuk dipedomani umat manusia dalam segala waktu dan tempat
\end{abstract}

Kata kunci: tafsir, al-Qur'an, dan ilmiah

\section{Pendahuluan}

Al-Qur'an merupakan kitab suci terakhiryang diturunkan Allah kepada Nabi Muhammad SAW untuk dijadikan sebagai hudan, bayyinah, dan furqan ${ }^{l}$ oleh umat manusia dalam setiap aspek hidup dan kehidupannya. Ia memiliki kedudukan yang sangat sentral dalam setiap sendi kehidupan dan selalu relevan dengan kebutuhan dan perkembangan ilmu pengetahuan dan teknologi di masa kini maupun mendatang (sholihun li kulli zaman wal makan).

Sebagai kitab yang terakhir diturunkan, alQur'an tidak hanya memuat pesan-pesan ilahiyah tentang moralitas universal kehidupan dan masalah spritualitas, tetapi juga menjadi sumber ilmu pengetahuan yang unik sepanjang kehidupan umat manusia. Al-Qur'an senantiasa mengajak para pembaca mampu melakukan kerja-kerja penafsiran yang maksimal untuk menemukan pesan-pesan Allah

\footnotetext{
${ }^{1}$ Lihat QS. al-Baqarah ayat 185.
}

SWT yang bisa dijangkau baik yang tersurat maupun yang tersirat, ayat-ayat qauliyyah maupun kawniyyah, sehingga ia bisa menjadi pedoman dan petunjuk. Artinya, Allah SWT sepertinya memberikan kesempatan kepada umat manusia untuk menginterpretasi isi al-Qur'an sesuai dengan kemampuannya dengan tetap berpijak pada visi dasar al-Qur'an sebagai rahmatan lil alamin. Banyak sekali ayat-ayat yang menunjukkan tentang berbagai hakekat yang mengajak manusia untuk mengeksplorasi ayatayat al-Qur'an yang berdimensi ilmiah, ${ }^{2}$ dan

\footnotetext{
${ }^{2}$ Antara lain, misalnya tentang fenomena alam seperti yang diisyaratkan-Nya: "Sesungguhnya dalam penciptaan langit dan bumi, dan silih bergantinya malam dan siang terdapat tanda-tanda bagi orang-orang yang berakal, (yaitu) orang-orang yang mengingat Allah sambil berdiri atau duduk atau dalam keadan berbaring dan mereka memikirkan tentang penciptaan langit dan bumi (seraya berkata): "Ya Tuhan kami, tiadalah Engkau menciptakan ini dengan sia-sia, Maha Suci Engkau, maka peliharalah kami dari siksa neraka.” (QS. Ali 'Imran: 190-191).
} 
berusaha menafsirkan serta menggali makna yang terkandung di dalamnya, sehingga menjadikannya sebagai inspirasi untuk menghasilkan penemuanpenemuan baru sesuai dengan semakin berkembangnya sains dan teknologi.

Upaya penafsiran terhadap al-Qur'an telah tumbuh dan berkembang sejalan dengan laju perkembangan dan kebutuhan umat Islam untuk mengetahui seluruh segi kandungan al-Qur'an serta intensitas perhatian para ulama' terhadap tafsir al-Qur'an. Salah satu dari beberapa corak baru dalam bidang penafsiran yang berdimensi ilmiah pada saat ini adalah penafsiran ilmiah atau dikenal dengan Tafsir 'Ilmy (Sciences Exegesis). Penafsiran ini dijadikan sebagai inspirasi untuk mengeksplorasi ayat-ayat al-Qur'an yang berdimensi ilmiah serta menghasilkan penemuanpenemuan baru yang bermanfaat bagi umat manusia. Tulisan ini merupakan kajian ulang (review) atas kontribusi teori ilmiah terhadap penafsiran dalam rangka me-refresh perkembangan pemikiran umat Islam, sehingga al-Qur'an senantiasa menjadi hudan li al-naas pada masa dan zaman yang tidak terbatas.

\section{Pengertian Tafsir 'Ilmy}

Dilihat dari segi kebahasaan, kata "Tafsir 'ilmy” berasal dari bahasa Arab yang terdiri dari dua akar kata, yaitu at-tafsir dan al-ilm. Kata tafsir merupakan mashdar (konjugasi) dari kata kerja "fassara-yufassiru-tafsiiran", yang artinya penjelasan atau keterangan. Dalam Kamus Besar Bahasa Indonesia (KBBI) Online, kata tafsir diartikan dengan keterangan atau penjelasan tentang ayat-ayat al-Qur' an agar maksudnya lebih mudah dipahami. ${ }^{3}$ Kata tafsir dalam arti ini dijumpai pada surat al-Furqan ayat 33 :

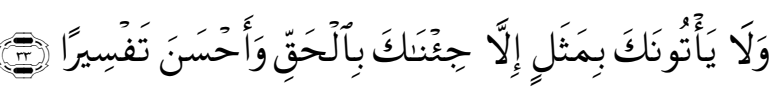 \\ Artinya: "Tidaklah orang-orang kafir itu datang kepadamu (membawa) sesuatu yang}

${ }^{3}$ http://kbbi.web.id/indek.php/w=tafsir. Diakses tanggal 12 April 2015. ganjil, melainkan Kami datangkan kepadamu suatu yang benar dan yang paling baik penjelasannya”(QS. 25: 33).

Sementara kata 'ilmi secara bahasa merupakan bentuk mashdar dari kata "'alima ya'lamu - 'ilman" yang berarti mengetahui atau memahami. ${ }^{4}$ Kata 'ilmi ini merupakan bentuk nisbah yang mendapat tambahan ya di akhirnya, sehingga menjadi 'ilmy artinya berhubungan dengan suatu ilmu. Kata ilm dan berbagai derivasinya kerap digunakan dalam al-Qur'an dalam arti umum pengetahuan (knowledge), termasuk untuk sains dan ilmu-ilmu kemanusiaan (sciences of nature and humanities). Selain itu, kata 'ilm dalam al-Qur'an juga digunakan untuk pengetahuan yang diwahyukan (revealed) sekaligus digunakan untuk pengetahuan yang diperoleh di luar wahyu (acquired). Dengan demikian, penggabungan kedua kata "tafsir “ilmy" tersebut secara etimologis berarti penjelasan atau perincian-perincian tentang ayatayat al-Qur'an, khususnya ayat-ayat tentang alam semesta dan realitas sosial yang dapat dipergunakan untuk kemaslahatan umat manusia.

Sedangkan pengertian "tafsir 'ilmy" secara terminologi pula, berbagai definisi yang telah dikemukakan oleh para ulama yang otoritatif dalam bidang ini, antara lain Husain Adz-Dzahabi dalam bukunya Tafsir wa alMufassirun misalnya, menyebutkan bahwa "Tafsir 'ilmy didefinisikan sebagai sebuah corak penafsiran al-Quran yang menggunakan pendekatan Teori-Teori ilmiah dan bertujuan untuk menggali Teori-Teori ilmiah dan pemikiran filosofis yang terkandung dalam ayat-ayat alQuran". ${ }^{5}$ Begitu pula menurut Fahd 'Abd AlRahman menjelaskan bahwa Tafsir 'Ilmy adalah

\footnotetext{
${ }^{4}$ Louis Ma'luf al-Yassu'i dan Bernand Toffel al-Yassu'i, al-Munjid al-Wasith fi al-'Arabiyyah al-Mu'ashirah (Beirut: Dar al-Masyriq, 2003), 749.

${ }^{5}$ Husain Adz-Dzahabi, Tafsir wa al-Mufassirun, Juz 2 (AlQahirah: Maktabah Wahbah, 2000), 474.
} 
suatu ijtihad mufassirnya untuk menangkap hubungan ayat-ayat kauniyah di dalam al-Quran dengan penemuan-penemuan ilmiah yang bertujuan memperlihatkan kemu'jizatan al-Quran yang menunjukkan atas sumbernya dan sesuai dengan waktu dan tempat". ${ }^{6}$

A. Mufakhir Muhammad mengutip pendapat Yusuf al-Qaradhawi menyebutkan bahwa tafsir bi al-ilmy adalah penafsiran yang menggunakan perangkat ilmu-ilmu kontemporer, realita-realita dan teorinya untuk menjelaskan sasaran dan makna al-Quran. ${ }^{7}$

Definisi Tafsir 'Ilmy lainnya dikemukakan pula Said Agil Husein al-Munawwar. Menurutnya tafsir 'ilmy adalah penafsiran ayat-ayat kauniyah yang terdapat dalam al-Quran dengan mengaitkannya dengan ilmu-ilmu pengetahuan modern yang timbul pada masa sekarang. ${ }^{8}$ Demikian pula menurut Muhammad Amin Suma, Tafsir 'ilmy adalah penafsiran al-Qur'an yang pembahasannya menggunakan pendekatan istilah-istilah (term-term) ilmiah dalam mengungkapkan al-Qur'an, dan seberapa dapat berusaha melahirkan berbagai cabang ilmu pengetahuan yang berbeda dan melibatkan pemikiran-pemikiran filsafat. ${ }^{9}$

Berdasarkan beberapa definisi yang dikemukakan di atas dapat dipahami bahwa tafsir 'ilmy adalah penafsiran terhadap ayat-ayat kawniyah (penciptaan alam semesta) dalam alQuran yang mengandung nilai-nilai ilmiah dengan pendekatan teori-teori ilmiah dan penemuan sains modern, yang bertujuan untuk memperlihatkan kemukjizatan al-Qur'an. Pada intinya Tafsir 'Ilmy merupakan sebuah upaya untuk mengeksplorasi

\footnotetext{
${ }^{6}$ Fahd bin Abdurrahman bin Sulaiman al-Rumi, Ittijahat al-Tafsir fi al-Qur'an al-Rabi' 'Asyar (Mamlakah al'Arabiyyah al-Su'udiyyah,1997), 549.

7 A. Mufakhir Muhammad, Tafsir 'Ilmi (Banda Aceh: Yayasan PeNA, 2004), 3-4.

${ }^{8}$ Said Agil Husein Al-Munawwar, Membangun Tradisi Kesalihan Hakiki (Jakarta: Ciputat Press, 2002), 72.

${ }^{9}$ Muhammad Amin Suma, Studi Ilmu-ilmu Al-Qur'an 2 (Jakarta: Pustaka Firdaus, 2001), 135.
}

ayat-ayat yang terdapat dalam al-Qur'an khususnya ayat-ayat kawniyyah dengan berbagai cara dan metode, sehingga dengan penafsiran ini akan dihasilkan teori-teori baru ilmu pengetahuan ataupun sesuatu yang berkesesuaian dengan ilmu pengetahuan modern. Hal ini sejalan dengan apa yang disebutkan Allah SWT dalam firman-Nya berikut:

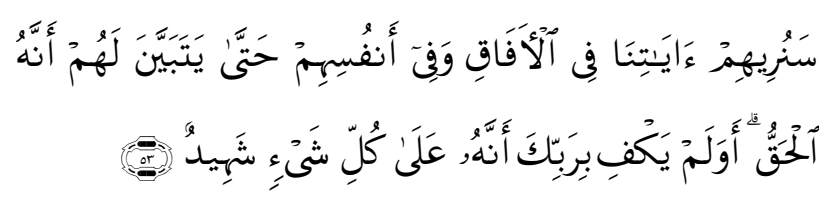

Artinya: "Kami akan memperlihatkan kepada mereka tanda-tanda (kekuasaan) Kami di segala wilayah bumi dan pada diri mereka sendiri, hingga jelas bagi mereka bahwa AlQuran itu adalah benar. Tiadakah cukup bahwa sesungguhnya Tuhanmu menjadi saksi atas segala sesuatu?" (QS. Fushshilat: 53).

Ayat di atas dapat dipahami bahwa apa yang diungkapkan al-Qur'an dapat dibuktikan kebenarannya melalui sains atau ilmu pengetahuan yang berkembang. Misalnya, antara lain firman Allah dalam surat Yasiin [36] ayat 38:

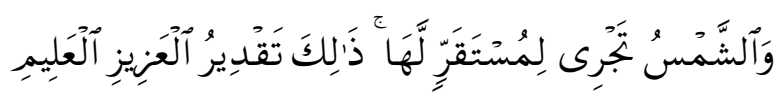
Artinya:"Dan matahari berjalan ditempat peredarannya. Demikianlah ketetapan yang Maha Perkasa lagi Maha mengetahui (QS. Yaasin: 38).

Pada masa-masa sebelumnya, para mufassir menafsirkan ayat ini dengan gerakan lahiriah matahari yang berjalan sehari-hari atau per musim. Akan tetapi, pada masa kini, berdasarkan penemuanpenemuan ilmiah dan sains baru, para ahli tafsir menafsirkan ayat tersebut dengan gerakan matahari menuju suatu titik tertentu yang di situ terdapat planet Vega. Semua penafsiran itu masih disertai dengan kehati-hatian dan bersifat moderatif. ${ }^{10}$

\footnotetext{
${ }^{10}$ Rohimin, Metodologi Ilmu Tafsir dan Aplikasi Model Penafsiran (Yogyakarta: Pustaka Pelajar, 2007), 97.
} 
Contoh lain pula dapat ditemukan misalnya pada firman Allah dalam surat QS. alBaqarah [2]: 61:

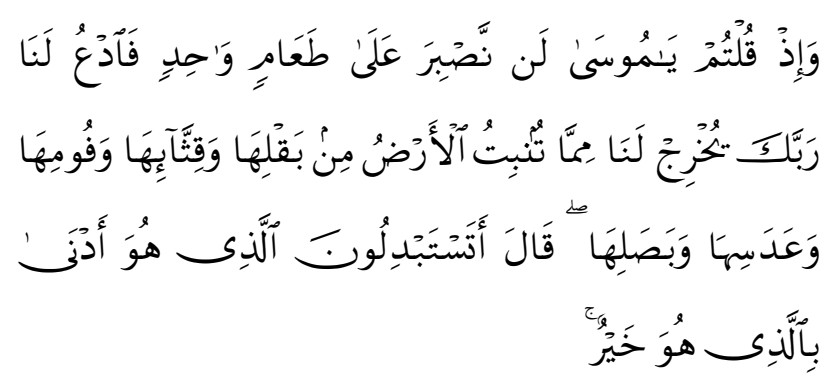

Artinya:"Dan (ingatlah), ketika kamu berkata: "Hai Musa, kami tidak bisa sabar (tahan) dengan satu macam makanan saja. Sebab itu mohonkanlah untuk kami kepada Tuhanmu, agar Dia mengeluarkan bagi kami dari apa yang ditumbuhkan bumi, yaitu sayurmayurnya, ketimunnya, bawang putihnya, kacang adasnya, dan bawang merahnya”. Musa berkata: "Maukah kamu mengambil yang rendah sebagai pengganti yang lebih baik?

Ayat ini bercerita tentang kaum Nabi Musa yang tidak puas dengan makan satu jenis makanan di pegunungan. Dalam hal ini, Thantowi Jauhari (w. 1940 M) mengomentari ayat ini dengan mengambil teori ilmiah Eropa, yakni bahwa model kehidupan Baduwi di pedesaan atau pegunungan, yang biasanya orang mengkonsumsi makanan manna wa salwa (jenis makanan yang tanpa efek samping) dengan kondisi udara yang bersih, jauh lebih baik daripada model kehidupan di perkotaan yang biasanya orang suka mengkonsumsi makanan siap saji, daging-daging, dan berbagai ragam makanan lainnya, ditambah lagi polusi udara yang sangat membahayakan kesehatan. $^{11}$

\section{Sekilas Penelusuran Tafsir 'Ilmy}

Dalam lintasan sejarah, perjalanan tafsir al-Quran sudah berlansung ketika Rasulullah

${ }^{11}$ Thantowi Jawhari, al-Jawahir fi Tafsir al-Qur'an alHakim, Juz I (t.tp.: Musthafa al-Halabi, t.th), 66-67.
SAW masih hidup, yakni pada saat al-Qur'an diturunkan. Rasulullah SAW berfungsi sebagai mubayyin (pemberi penjelasan). Beliau menjelaskan kepada sahabat-sahabatnya tentang arti dan kandungan al-Quran, khususnya menyangkut ayat-ayat yang tidak mereka pahami atau samar artinya. Kemudian setelah beliau wafat, usaha penafsiran al-Quran dilanjutkan oleh para shahabat dan para tabi'in dimana wahyu sudah sempurna diturunkan. Estafet kegiatan penafsiran al-Qur'an terus berkembang hingga masa sekarang.

Dalam peta keilmuan Islam, penafsiran alQuran terus berlanjut seiring berjalannya zaman dan semakin besarnya kebutuhan umat tehadap penjelasan tentang kandungan ayat-ayat al-Quran. Meskipun al-Qur'an telah berhenti, karena pewahyuan sudah berakhir dengan berakhirnya masa kenabian Muhammad SAW, namun alQuran selalu terbuka untuk difahami dan ditafsirkan oleh para pembacanya. Sementara di sisi lain, masalah-masalah yang timbul dalam lingkungan umat Islam, senantiasa berkembang seiring dinamika zaman. Maka untuk mempertemukan al-Qur'an dengan perkembangan zaman, para ulama melakukan upaya-upaya untuk menjadikan al-Qur'an mampu berbicara pada setiap zaman yang berbeda, melalui aktivitas penjelasan makna-makna al-Qur'an, dan usaha-usaha itu melahirkan suatu disiplin ilmu yang kemudian dikenal secara luas sebagai tafsir. ${ }^{12}$

Apabila disimak sejarah awal perkembangan tafsir, pada mulanya usaha penafsiran ayat-ayat alQur'an, muncul dua jenis penafsiran al-Qur'an secara estafet, yaitu tafsir bi al-Ma'tsur atau disebut

\footnotetext{
${ }^{12}$ Pengertian tafsir yang dikemukakan oleh ulama banyak sekali, antara lain misalnya Abu Hayan menjelaskan bahwa tafsir adalah ilmu yang membahas mengenai tata cara lafadz-lafadz al-Qur'an, dalil-dalil, aturan-aturan ditinjau dari kata (mufradat),susunan kalimat,serta penjelasan makna yang terkandung dalam susunan kalimat". Lihat Muhammad Hussein Adz-Dzahabi, Al-Tafsir Wa AlMufassiruun, Vol. II (Kairo, Maktabah Wahbah, 2003), 14.
} 
juga dengan tafsir bi ar-Riwayah ${ }^{13}$ dan tafsir bi ar-Ra'yi atau tafsir bi ad-Dirayah. ${ }^{14}$ Akan tetapi, sejalan dengan lajunya dinamika masyarakat, berkembang dan bertambah besar pula porsi peranan akal atau ijtihad dalam penafsiran ayatayat al-Quran, maka tidak heran muncul berbagai kitab atau penafsiran yang beraneka ragam metode dan coraknya. Masing-masing ulama menggunakan cara dan pendekatan yang berbeda dalam menafsirkan al-Quran sesuai dengan dinamika zaman dan perkembangan ilmu pengetahuan. Salah satu corak penafsiran alQur'an itu adalah penafsiran ilmiah atau yang dikenal dengan sebutan tafsir al- ilmy.

Dalam hal ini, kehadiran tafsir 'ilmy berangkat dari sebuah asumsi bahwa al-Qur'an merupakan kitab suci yang di dalamnya mengandung berbagai informasi ilmu, baik yang terkait dengan persoalan agama maupun isyaratisyarat ilmu pengetahuan. Kecenderungan penafsiran al-Qur'an secara ilmiah ini sebenarnya sudah muncul benihnya semenjak masa perkembangan ilmu pengetahuan di era dinasti Abbasiyah, khususnya pada masa pemerintahan Harun ar-Rasyid (169-194 H) dan al-Makmun (198-215 H). ${ }^{15}$ Kecenderungan tafsir 'ilmy saat itu terjadi sebagai efek dari tranformasi ilmu pengetahuan dan keinginan para ulama untuk

\footnotetext{
${ }^{13}$ Pengertian Tafsir bi al-Ma'tsur adalah penafsiran ayatayat al-Qur'an yang didasarkan dan mengutip ayat-ayat alQur'an yang lain, Sunnah yang tertuang dalam hadits-hadits Nabi, pendapat Shahabat dan Tabi' in. Lihat Manna' Khalil al-Qattan, Mabahits fi 'Ulumi al-Qur'an (Riyadh: Mansyuraat al-'Ashar al-Hadits, 1973), 347.

${ }^{14}$ Sedangkan Tafsir bi ar-Ra'yi adalah penafsiran al-Qur'an yang didasarkan pada pendapat pribadi mufassir setelah terlebih dahulu memahami bahasa dan adat istiadat bangsa Arab. Lihat Manna' Khalil al-Qattan, 351.

${ }^{15}$ Al-Makmun sendiri merupakan putra khalifah Harun alRasyid yang dikenal sangat cinta dengan ilmu. Salah satu karya besarnya yang terpenting adalah pembangunan Bait al-Hikmah, pusat penerjemahan yang berfungsi sebagai perguruan tinggi dengan perpustakaan yang besar. Pada masa inilah, Islam mencapai peradaban yang tinggi sebagai pusat kebudayaan dan ilmu pengetahuan dunia. Lihat Badri Yatim, Sejarah Peradaban Islam (Jakarta: Rajawali Pers, 2010), 53.
}

melakukan kompromi antara ajaran Islam "alQur'an" dengan perkembangan peradaban dunia luar, dan juga sebagai akibat gerakan penerjemahan buku-buku asing ke dalam dunia Islam dan perkembangan yang terjadi di dunia Islam itu sendiri. ${ }^{16}$ Gagasan ini selanjutnya ditekuni oleh imam Abu Hamid al-Ghazali (450$505 \mathrm{H}$ ) dan ulama-ulama lain yang sependapat dengan dia.

Abu Hamid al-Ghazali (selanjutnya disebut Al-Ghazali) disebut-sebut sebagai salah satu tokoh generasi awal, di mana dianggap ikut memberikan legitimasi terhadap munculnya penafsiran 'ilmy ini. Hal itu ditunjukkan melalui ungkapan-ungkapan dan riwayat-riwayat yang disebutkan dalam beberapa karyanya. Di antaranya dalam buku Ihya' Ulumuddin, beliau mengutip kata-kata Ibnu Mas'ud: "jika seseorang ingin memiliki pengetahuan masa lampau dan pengetahuan modern, selayaknya dia merenungkan al-Qur'an'. Selanjutnya beliau menambahkan "ringkasnya, seluruh ilmu tercakup di dalam karyakarya dan sifat-sifat Allah, dan al-Qur'an adalah penjelasan esensi, dan sifat-sifat dan perbuatanNya. Tidak ada batasan terhadap ilmu-ilmu ini dan di dalam al-Qur'an terdapat indikasi pertemuannya (al-Qur'an dan ilmu-ilmu). ${ }^{17}$

Dunia Islam pada masa itu berada pada puncak peradaban dunia, ilmu pengetahuan dari luar diadopsi lewat penerjemahan buku-buku ilmiah. Semua kegiatan ini mendapat dukungan dan dorongan dari pemerintah saat itu. Karyakarya klasik dari peradaban pra-Islam seperti Yunani, Persia, dan India dipelajari. Dari berbagai kajian terhadap keilmuan luar itu, pengetahuan dari dalam Islam sendiri seperti ilmu kalam, fikih, ushul fiqih dan dari luar seperti filsafat, fisika, kedokteran menjadi berkembang. Kajian-kajian terhadap berbagai macam bidang ilmu digalakkan,

\footnotetext{
${ }^{16}$ Abd al-Majid Abd al-Salam al-Muhtasib, Ittijahat alTafsir al-Asr al-Hadits (Beirut: Dar al-Fikr, 1987), 245.

${ }_{17}$ Mahdi Ghulsyani, Filsafat Sains Menurut al-Qur'an (Bandung: Mizan, 1994), 137.
} 
diskusi-diskusi keilmuan pun ramai digelar. Untuk memperkuat argumennya masing-masing, mereka menggali dari ayat-ayat al-Qur'an. Lahirlah berbagai corak penafsiran seperti tafsir hukum, falsafi, sufi, teologi tertentu yang mendukung pemikiran mereka. Kecenderungan tafsir 'ilmy juga demikian halnya, terjadi karena adanya upaya untuk melakukan kompromi antara ajaran Islam (baca: al-Qur'an) dengan perkembangan peradaban dunia luar Islam. ${ }^{18}$ Pada masa ini lahir kitab tafsir 'ilmy Mafatih al-Gaib karya Fakhruddin al-Razi (w. 606 H). Hal ini diakui oleh seluruh penulis Ahlusunnah dan riset lapangan juga membuktikan hal itu. ${ }^{19}$

Meskipun demikian, sebelum Fakhruddin al-Razi, al-Ghazali (450-505 H) dalam bukunya “Jawahir Al-Qur'an" juga telah menyebutkan penafsiran beberapa ayat al-Qur'an yang dipahami dengan menggunakan beberapa disiplin ilmu, seperti astronomi, perbintangan, kedokteran, dan lain sebagainya. Jika upaya al-Ghazali ini dianggap sebagai langkah pertama bagi kemunculan penafsiran ilmiah, tidak diragukan lagi bahwa alGhazali sendiri belum berhasil merealisasikan metode tersebut, setelah satu abad berlalu, barulah Fakhruddin al-Razi di dalam karyanya "Mafatih al-Ghaib"-nya berhasil merealisasikan metode penafsiran yang pernah menjadi percikan pemikiran al-Ghazali itu. ${ }^{20}$

Pasca masa Fakhruddin al-Razi, tendensi penafsiran ilmiah ini diteruskan dan menghasilkan buku-buku tafsir yang sedikit banyak terpengaruh oleh teori penafsiran Fakhruddin al-Razi dalam ruang lingkup yang agak terbatas. Di antaranya adalah Ghara'ib Al-Qur'an wa Ragha'ib alFurqan karya An-Nasyaburi (w. 728 H), Anwar atTanzil wa Asrar at-Ta' wil karyaAl-Baidhawi (w. 791

\footnotetext{
${ }^{18}$ Abdul Mustaqim, Pergeseran Epistemologi Tafsir (Yogyakarta: Pustaka Pelajar, 2005), 64.

${ }^{19}$ Sayid Musa Husaini, "Metode Penafsiran Saintis di dalam Buku-buku Tafsir Modern"; diperoleh dari http:// quran.al-shia.com/id/metode/01.htm. di akses: 11 Oktober 2012.

${ }^{20}$ Rohimin, 94.
}

H), dan Ruh al-Ma'ani fi Tafsir al-Qur'an al-Adzim wa Sab'al-Matsani karya Al-Alusi (w. 1217 H).

Selain mereka yang disebut di atas, terdapat beberapa mufassir lagi, seperti Ibn Abul Fadhl al-Marasi (w. 655 H), Badruddin azZarkasyi (w. 794 H), dan Jalaluddin as-Suyuthi (w. $911 \mathrm{H}$ ), yang termasuk dalam golongan para mufassir yang memiliki tendensi penafsiran saintis. Meskipun demikian, sebenarnya para mufassir ini tidak dapat dimasukkan ke dalam kategori mufassirin yang memiliki aliran saintis dalam menafsirkan al-Qur'an, karena mereka hanya mengklaim bahwa al-Qur'an memuat semua jenis dan disiplin ilmu pengetahuan, dan hanya klaim ini tidak dapat dijadikan bukti bahwa mereka memiliki tendensi penafsiran saintis.

Pada perkembanganm berikutnya, tafsir 'ilmy kian marak. Umat Islam dikejutkan oleh kenyataan bahwa mereka sedang berada dalam keterbelakangan. Kondisi fisik dan keilmuannya mereka memprihatinkan. Sementara itu Eropah mengalami kemajuan dalam hal ilmu pengetahuan dan teknologi. Banyak dari bangsa Eropa yang berdatangan ke belahan Timur, menjajah dengan bantuan sains dan teknologinya. Untuk mengatasi ketertinggalan itu, segolongan pemikir Islam mulai mengadakan pembaharuan. Salah satunya adalah dengan mengadopsi ilmu pengetahuan luar ke dalam ajaran Islam. Kemajuan Barat bermula dari kemenangan para ilmuan terhadap agama Kristen, di mana temuan-temuan ilmiah bertentangan dengan kebenaran al-Kitab. Kemenangan ini kemudian dijadikan alasan oleh Barat untuk menunjukkan bahwa kemunduran Islam adalah juga disebabkan oleh kitab suci al-Qur'an. Untuk menanggapi hal tersebut, umat Islam berupaya membuktikan kitab al-Qur'an tidak bertentangan dengan temuan-temuan sains dan kemajuan, salah satunya adalah lewat tafsir 'ilmy. ${ }^{21}$ Pada masa ini, metode penafsiran saintis mengalami kemajuan

\footnotetext{
${ }^{21}$ Wildana Wargadinata, "Perkembangan Pemikiran Zaman Abbasiah Sebagai Akar Tafsir 'ilmy Abad Modern", dalam Jurnal el-Harakah 9, No. 1 (2007), 24.
} 
yang pesat. Tercatat sejumlah mufassir yang menekuni metode ini, seperti; Muhammad bin Ahmad al-Iskandarani (w. 1306 H), dalam Kasyf al-Asrar an-Nuraniyah al-Qur'aniyah-nya, AlKawakibi (w. 1320 H), dalam Thaba 'i al-Istibdad wa Mashari al-Isti'bad-nya, Muhammad Abduh (w.1325 H) dalam Tafsir Juz'Amma-nya, dan AthThanthawi (w.1358 H) dalam Jawahir al-Qur'an, masing-masing menafsirkan ayat-ayat al-Qur'an secara saintis.

Kemudian perkembangan selanjutnya, pemikiran penafsiran secara ilmiah mengalami perkembangan yang lebih pesat sampai sekarang, sehingga memberi dorongan yang cukup besar bagi para ilmuan untuk menulis buku tafsir yang didasarkan atas pemikirin ilmiah secara tematik (al-maudhu'i). ${ }^{22}$ Berbagai kitab penafsiran ilmiah yang bersifat maudhu'iy yang muncul, seperti Afzalurrahman dengan Qur'anic Sciences-nya dimana menurutnya “al-Qur'an dan ilmu pengetahuan itu sama-sama mengandung kebenaran, dan tidak ada pertentangan di antara keduanya". ${ }^{23}$ Ada juga Maurice Bucaille dengan The Bible, The Qur'an and Science-nya, Abbas Mahmud al-'Aqqad dengan Tafsir al-Falsafah alQur'aniyah-nya dan masih banyak lagi tafsirtafsir lainnya.

\section{Latar Belakang Kemunculan dan Tokoh- Tokohnya}

Apabila dilihat dari rentetan sejarah, tafsir 'ilmy dilatari beberapa faktor yang secara umum dapat dibagi menjadi dua: Pertama faktor internal yakni faktor-faktor yang berada dalam teks ayatayat al-Qur'an sendiri. Adanya ayat-ayat alQur'an yang tidak sedikit memuat ayat-ayat kauniah (alam semesta), di mana hal ini mendorong para mufassir untuk mendalaminya lebih jauh dengan menggunakan perangkat ilmu pengetahuan, seperti disebut dalam QS. al-A'raf

\footnotetext{
${ }^{22}$ Rohimin, 95-96.

${ }^{23}$ Afzalur Rahman, Qur'anic Sciences (London: The Muslim Schools Trust, 1981), 1.
}

[07]: 54, Yaasin [36]: 80, an-Naml [27]: 88 dan lain-lain. Disamping itu juga ada ayat-ayat alQur'an yang menganjurkan manusia, baik secara eksplisit maupun implisit untuk memperhatikan fenomena alam, di samping juga keinginan untuk mengetahui dimensi kemukjizatan al-Qur'an, seperti dalam QS. Fushshilat [41]: 53, QS. alGhasysyiah [88]: 17-20 atau al-Anbiya' [21]: 30. Selain itu, adanya pernyataan al-Qur'an yang disinyalir oleh sebagian mufassir menunjukkan bahwa al-Qur'an merupakan kitab yang memuat segala macam ilmu pengetahuan, seperti QS. anNahl [16]: 89 dan al-An'am [06]: 38. Kedua, faktor eksternal yakni faktor-faktor di luar teks al-Qur'an yang berkaitan dengan adanya perkembangan ilmu pengetahuan dan sains modern, yang meliputi kondisi sosial dan budaya umat Islam yang mulai bersentuhan dengan perkembangan kemajuan ilmu pengetahuan di dunia luar. Kondisi subjektif penafsir sendiri yang mempunyai disiplin keilmuan dibidang sains. Pengaruh pertentangan Gereja dengan kalangan ilmuan di Eropa yang pada akhirnya dimenangkan oleh para ilmuan dan jatuhnya otoritas kebenaran agama sebagai pusat kebenaran. Kondisi politik, di mana di abad modern, dunia Islam dijajah bangsa Barat dengan kecanggihan teknologinya, sementara umat Islam tertinggal jauh di belakang, ini mengakibatkan tumbuhnya rasa rendah diri di dunia Islam. Untuk mengatasi hal ini, maka langkah-langkah politis dilakukan agar umat Islam bangkit dari kegelapan, salah satunya mempelajari ilmu pengetahuan, atau dengan mengataskan pengetahuan Barat itu diklaim sudah terkandung dalam al-Qur'an.

Menurut Quraish Shihab, meluasnya corak penafsiran ilmiah ini setidaknya dipengaruhi oleh dua faktor, yang pertama adalah merupakan reaksi terhadap ketertinggalan umat Islam dalam bidang kemajuan ilmu pengetahuan dan teklnologi dari dunia Barat. Oleh karena ketertingggalan ini, mereka berusaha mencari kompensasi sebagai sebuah shock therapy atau sebagai salah satu upaya untuk menutupi rasa rendah diri yang 
berlebihan (inferiority complex) yang melanda mereka. Salah satunya dengan mengingat kejayaan-kejayaan yang pernah diraih umat Islam pada masa lalu yang baik secara langsung maupun tidak langsung berpengaruh terhadap perkembangan masyarakat Islam dalam menafsirkan al-Qur'an. Maka tidaklah mengherankan ketika ada penemuan baru, para cendekiawan muslim sepertinya berlomba-lomba untuk mencari ayat-ayat al-Qur'an yang berkesesuaian dengan penemuan tersebut dan serta merta mengatakan bahwa apa yang ditemukan sebenarnya sudah tercantum dalam al-Qur'an. Faktor kedua yang menjadikan cendekiawan muslim melakukan hal ini sebagai reaksi atas resistansi yang besar dari gereja terhadap ilmu pengetahuan yang dikarenakan adanya pertentangan penemuan ilmiah dengan kepercayaan atau teori-teori tertentu yang diyakini kebenarannya dan kesuciannya oleh Gereja. Pertentangan ini mengakibatkan terjadinya kekejaman dan penindasan terhadap ilmuwan yang dianggap kafir dan berhak mendapat kutukan. Hal ini menimbulkan keyakinan di kalangan umum bahwa ilmu pengetahuan bertentangan dengan agama. Pertentangan antara agama dengan ilmu pengetahuan ini memberikan pengaruh terhadap cendekiawan muslim. Mereka khawatir kalaukalau penyakit pertentangan ini timbul pula dalam dunia Islam, sehingga mereka senantiasa berusaha membuktikan hubungan yang sangat erat antara ilmu pengetahuan dengan agama terutama al-Qur'an walaupun terkadang langkah mereka terlampau jauh dalam membuktikan hal itu. ${ }^{24}$

Adapun tokoh-tokoh penafsir 'ilmy kontempoter selain yang di sebut di atas, menurut Ali Hasan Al-'Aridl adalah:

1. Dr. al-Kauniyah Ahmad Al-Ghamrawi dalam kitabnya Sunanullah al-Kauniyah dan alIslam fi 'Ashr al-'ilm.

\footnotetext{
${ }^{24}$ M. Quraish Shihab, Membumikan Al-Qur,an: Fungsi dan Peran Wahyu dalam Kehidupan Masyarakat, Cet. XIX (Bandung: Mizan, 1999), 102.
}

2. Dr. Abdul Aziz dalam al-Islam wa al-Thib alHadits.

3. Al-Syekh Thanthawi Jauhari.

4. Ahmad Mukhtar al-Ghozali dalam Riyadh alMukhtar.

5. Al-Ustadz Hanafi Ahmad dalam al-Tafsir al'ilmi Li al-Ayat al-Kauniyah fi al-Qur'an alKarim.

6. Al-Alamah Wahid al-Din Khan dalam alIslam Yatahadda.

7. Dr. Jamal al-Din al-Fandy dalam al-Ghida wa al-Dawa' dan

8. Ustadz 'Abd al-Razzaq Naufal dalam alQur'an wa al- 'ilm al-Hadist. ${ }^{25}$

Sedangkan menurut Abdul Majid Abdussalam al-Muntasib, tokoh-tokoh penafsir 'ilmy kontemporer lainnya, yaitu:

1. As-Syekh Muhammad Abduh.

2. Muhammad Jamaluddin al-Qasimi dalam Mahaasinu at-Ta'wil.

3. Mahmud Syukri al-Aluusi (w. 1992 M) dalam buku Maa Dalli 'Alaihi al-Qur'anu Mimmaa ya'dhidu al-Hai'ata al-Jadiidata alQawiimatu al-Burhan (Dalil-dalil al-Qur'an yang meneguhkan ilmu astronomi modern, dengan argumentasi kuat).

4. Abdul Hamid bin Badis dalam Tafsiru Ibni Badis fii Majaalisi at-Tadzkiiri min Kalaami al-Hakimi al-Khabiir (Tafsir Ibnu Badis mengenai Firman Dzat Yang Maha Bijak dan Maha Tahu dalam forum-forum kajian).

5. Musthafa Shadiq ar-Rafi'i dalam bukunya I'jaazu al-Qur'ani wa Balaghtu anNabawiyah (Mukjizat al-Qur'an dan Balaghah Kenabian). ${ }^{26}$

\footnotetext{
${ }^{25}$ Ali Hasan Al-‘Aridl, Sejarah dan Metodologi Tafsir, Terj. Ahmad Akram, cet. II (Jakarta: PT. Raja Grafindo Persada, 1994), 62-63.

${ }^{26}$ Abdul Majid Abdussalam al-Muntasib, Visi dan Paradigma Tafsir Al-Qur'an Kontemporer, terj. Mohammad Maghfur Wachid. Judul asli Ittijaahat atTafsiir fi al-Ashri ar-Rahin (Bangil: Al-Izzah, 1997), 279.
} 


\section{Sikap Para Ulama Terhadap Tafsir 'Ilmy}

Penafsiran secara 'ilmy, di samping bertujuan membenarkan dan mengkompromikan teori-teori ilmu pengetahuan dengan al-Qur'an, juga bertujuan menggali ilmu pengetahuan dari ayat-ayat al-Qur'an. Pada dasarnya tafsir 'ilmy berangkat dari sebuah asumsi bahwa kitab suci al-Qur'an tidak bertentangan dengan akal sehat manusia dan mengandung berbagai macam ilmu, baik yang terkait dengan ilmu agama maupun ilmu pengetahuan umum. Meskipun demikian, kehadiran tafsir 'ilmy masih mendatangkan berbagai komentar dikalangan para ulama; ada yang mendukung, yang menentang, dan bahkan ada yang bersikap moderat.

Adapun ulama yang mendukung dan bersikap terbuka terhadap kehadiran tafsir 'ilmy, antara lain:

1. Al-Ghazali, adalah orang yang paling banyak memasarkan tafsir 'ilmiyah di tengah percaturan keilmuan Islam. Dalam kitabnya Ihya' 'Ulumuddin pada pasal IV menyinggung mengenai pemahaman dan penafsiran alQur'an secara rasional tanpa menggunakan naql (al-Qur'an dan hadits). Beliau sepakat dengan pendapat beberapa ulama bahwa alQur'an mengungkapkan 77.200 macam/buah ilmu, karena setiap kata merupakan sebuah ilmu. Dengan mengutip hadis dari Ibn Mas'ud yang menyatakan bahwa Nabi pernah bersabda:

$$
\text { عن ابن مسعود رضي الله عنه انه قال: من اراد علم }
$$

Artinya: "Dari Ibn Mas'ud ra. ia berkata: "Barang siapa ingin memperoleh pengetahuan tentang beberapa permulaan dan beberapa kesudahan, maka kajilah alQur'an dengan seksama."(HR. Ibn Mas'ud).

Beliau mengatakan bahwa segala sesuatu yang sulit dipahami dengan penginderaan dan penalaran sehingga menimbulkan berbagai teori yang berlawanan satu sama lain sebenarnya sudah dikemukakan dan dirumuskan dalam al-Qur'an dan semuanya dapat diketahui oleh para pemikir. ${ }^{27} \mathrm{Al}$ Ghazali juga berpendapat dalam kitab "Jawahir al-Qur'an" bahwa segala macam ilmu itu termasuk dalam af'al (perbuatanperbuatan Allah dan sifat-sifatnya). Pengetahuan tersebut tidak terbatas. Dalam alQur'an terdapat isyarat-isyarat menyangkut prinsip-prinsip pokoknya. Hal terakhir ini, antara lain dibuktikan dengan mengemukakan ayat:

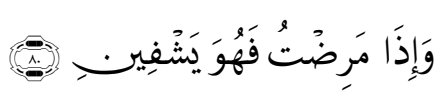

Artinya: "Dan apabila aku sakit, Dialah yang menyembuhkan Aku”(QS. AsySyu'araa: 80).

Menurut al-Ghazali, "Obat" dan "penyakit" tidak dapat diketahui kecuali oleh yang berkecimpung dibidang kedokteran. Dengan demikian, ayat di atas merupakan isyarat tentang ilmu kedokteran. ${ }^{28}$

2. Al-Marasi, seperti yang diungkapkan kembali oleh as-Syuyuti dalam tafsirnya mengatakan bahwa ilmu ukur disebut dalam al-Qur'an: "Pergilah kamu mendapatkan naungan" yang mempunyai tiga cabang” (QS. alMursalat: 30). Beliau juga menyatakan bahwa Al-Jabar dan Aritmatik ditemukan dari hurufhuruf lepas pada permulaan beberapa buah

${ }^{27}$ Al-Ghozali, Ihya' 'Ulumuddin, Jilid I (Kairo: Al-Tsaqofah al-Islamiyah, 1356 H), 301. Lihat juga M. Quraish Shihab, 101.

${ }^{28}$ Al-Ghozali, Jawahir Al-Qur'an, Cet. 1 (Mesir: Percetakan Kordistan, 1329 H), 31-32.

${ }^{29}$ Yang dimaksud dengan naungan di sini bukanlah naungan untuk berteduh, akan tetapi asap api neraka yang mempunyai tiga gejolak, yaitu di kanan, di kiri dan di atas. ini berarti bahwa azab itu mengepung orang-orang kafir dari segala penjuru. 
surat al-Qur'an, karena dalam huruf-huruf itu mengandung keterangan tentang kurun waktu, tahun-tahun dan hari-hari terjadi peristiwaperistiwa sejarah bangsa-bangsa terdahulu dan juga keterangan kelangsungan hidup ummat Muhammad SAW sekarang. Dari pernyataan itu tampak jelas al-Marasi berpegang pada pendirian bahwa ilmu-ilmu pengetahuan bisa ditemukan dan diformulasikan dari alQur'an. ${ }^{30}$

3. Al-Kawakibi, mengatakan bahwa ilmu-ilmu pengetahuan termasuk penemuan teori-teori ilmiah di Eropa dan Amerika sekarang, sebenarnya sejak abad 13 yang lalu telah dijelaskan dan diisyaratkan dalam al-Qur'an. Hal-hal yang masih belum terungkap pada saat ditemukannya, nanti akan menjadi bukti kemukjizatan al-Qur'an. ${ }^{31}$

4. Fakhruddin ar-Razi, walaupun tidak sepenuhnya sependapat dengan al-Ghozali, namun dalam tafsirnya "Mafatih Al-Ghayb", dipenuhi dengan pembahasan ilmiah menyangkut filsafat, teologi, ilmu alam, astronomi, kedokteran, dan sebagainya.

5. Hal-hal senada juga dipegangi oleh Imam alSyuyuti dalam al-Itqan, Al-Baidhawi dalam kitab Anwaaru at-Tanzil wa Asraaru atTa'wil, An-Naisaburi yang lebih dikenal dengan an-Nadhdham al-A'raj (penyair yang pincang) dalam kitabnya Gharaibu Al-Qur'an wa Raghaibu al-Furqaani, dan Az-Zarkasyi dalam kitabnya Al-Burhan fii 'Ulumul AlQur'an. ${ }^{32}$ Dan juga disampaikan ulama modern seperti Thantawi Jauhari dan ulama sebelumnya, bahkan Rasyid Ridha (w. 1935 M), dalam Tafsir al-Manar menyatakan: "AlQuran mencakup segala hakikat ilmiah yang diungkap oleh pendapat-pendapat kontemporer, khususnya bidang filsafat dan sosiologi". ${ }^{33}$

\footnotetext{
${ }^{30}$ M. Husain al-Zahabiy, 113-114.

${ }^{31}$ Ibid., hal. 115

${ }^{32}$ Ali Hasan Al-‘Aridl, 64.

${ }^{33}$ Lihat M. Quraish Shihab, 102.
}

Secara umum, argumentasi yang mereka kemukakan untuk mendukung penafsiran 'ilmy ini, antara lain:

1. Allah SWT memberikan peluang luas untuk melakukan istidlal (penarikan kesimpulan dan pelajaran) dari hal-hal yang Allah SWT tampilkan dalam al-Qur'an, seperti keadaan bumi dan langit, pergantian siang dan malam, tingkah pola pergerakan dan keadaan bendabenda angkasa dan keadaan alam lainnya. Apabila mengkaji hal-hal seperti itu tidak diperkenankan, maka tentunya hal-hal tersebut tidak ditampilkan dalam al-Qur'an.

2. Firman Allah SWT dalam al-Qur'an yang berbunyi:

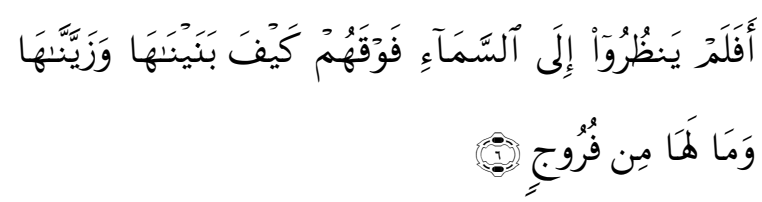

Artinya: "Maka apakah mereka tidak melihat akan langit yang ada di atas mereka, bagaimana kami meninggikannya dan menghiasinya dan langit itu tidak mempunyai retak-retak sedikitpun?"(QS. Qaaf: 6).

Dalam ayat tersebut Allah SWT mendorong untuk melakukan perenungan dan pemikiran tentang bagaimana kejadian tersebut, yaitu:

1. Dengan menggunakan pendekatan tafsir 'ilmy, penemuan-penemuan baru bisa digunakan sebagai penegasan terhadap kemukjizatan yang terdapat dalam al-Qur'an.

2. Allah SWT akan mengisi jiwa seseorang dengan keimanan terhadap keagungan-Nya ketika ia menafsiri al-Qur'an dengan ayat-ayat tertentu dan makhluk-makhluk yang sangat renik dengan menggambarkannya melalui ilmu pengetahuan yang ada. ${ }^{34}$

\footnotetext{
${ }^{34}$ Fahd ibn Abdurrahman Al-Rumi, Buhuts fi Ushul alTafsir wa Minhajuhu (t.tp: Maktabah al-Taubah, t.th.), 97.
} 
Dan juga didasarkan pada firman Allah SWT:

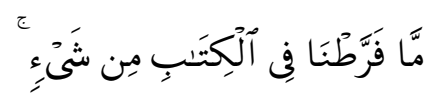

Artinya:"Tiadalah Kamialpakan sesuatupun dalam Al-Kitab" (QS. Al-An'am: 38).

Dan firman Allah SWT yang lain:

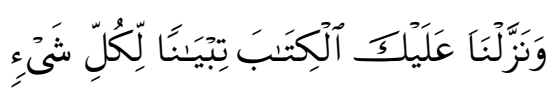

Artinya: "Dan Kami turunkan kepadamu al-Kitab (Al-Qur'an) untuk menjelaskan segala sesuatu” (QS. an-Nahl: 89).

Selain ada yang menerima, ada pula di kalangan ulama yang menentang kehadiran tafsir 'ilmy, antara lain:

1. Abu Ishaq Ibrahim bin Musa as-Syatibi alAndalusia (w. $790 \mathrm{H}$ ) dalam kitabnya alMuwafaqat menyatakan sebagai ketidak setujuannya terhadap tafsir 'ilmy, ".....banyak yang bersikap keterlaluan dalam memahami al-Qur'an sehingga mereka mengaitkannya dengan semua ilmu pengetahuan baik yang disebut orang-orang dahulu maupun orangorang sekarang. Lebih lanjut seperti yang dinukilkan Al-Dzahabi, beliau mengatakan bahwa ulama salaf yang saleh dari kalangan sahabat, tabi'in dan tabi'at adalah orangorang yang paling tahu tentang al-Qur'an, tentang ilmu-ilmunya dan kandungan isinya, namun kita tidak pernah mendengar bahwa mereka membicarakan hal-hal sebagaimana mereka pegangi itu....." Al-Qur'an memang tidak dimaksudkan untuk memberikan pengakuan atas kebenaran pendapat mufassir 'ilmi. ${ }^{35}$

2. Abu Hayyan al-Andalusi, Muhammad Rasyid Ridha, as-Syeikh Mahmud Syaltut, as-Syeikh Muhammad Musthafa al-Maraghi, Muhammad Izzat Darwazat, Amir al-Khauli, Syauqi Dhaif

${ }^{35}$ Ali Hasan Al-‘Aridl., 65. dan Muhammad Maghfur Wachid mengatakan, “.....saya tegaskan, bahwa saya menolak tendensi tafsir al-Qur'an ilmiah. Saya tidak membenarkan praktik menunjukkan ayat-ayat al-Qur'an pada ilmu pengetahuan alam murni....". ${ }^{36}$

3. Muhammad al-Ghozali, mengungkapkan ketidak setujuannya, berangkat dari problem I'jaz al-'Ilmi (mukjizat keilmuan) dalam alQur'an. Bila kita melihat secara seksama pada sebagian isyarat ilmiah yang ada dalam alQur'an, lalu dibandingkan dengan ilmu-ilmu modern, masalah I'jaz al-'Ilmi di dalam alQur'an adalah pendapat yang riskan. Seandainya yang disebut adalah I'jaz al- 'Ilmi berarti kekalnya ketidakmampuan manusia untuk mencapai sesuatu yang mampu dicapai al-Qur'an termasuk mencapai esensi-esensi, ketentuan-ketentuan ilmiah, dan sebagainya maka I'jaz untuk dunia saat ini tidaklah berarti terungkap sejumlahnya hukum ilmu pengetahuan oleh manusia sebagaimana telah dicapai dan dibuktikan al-Qur'an dan apa yang diisyaratkan al-Qur'an merupakan I'jaz pada kurun tertentu. ${ }^{37}$

Sedangkan orang-orang yang menolak adanya penafsiran 'ilmy terhadap al-Qur'an semacam ini, mereka berargumen bahwa:

1. Kemukjizatan Al-Qur'an ialah sudah menjadi suatu yang pasti dan tidak butuh hal-hal lain untuk menjelaskannya seperti penfasiran macam ini terkadang bisa mengaburkan kemukjizatan Al-Qur'an.

2. Dorongan Al-Qur'an untuk melakukan penalaran dan perenungan pada peristiwa dan ilmu-ilmu merupakan suatu ajakan yang menyeluruh dan bersifat pengambilan pelajaran

\footnotetext{
${ }^{36}$ Abdul Majid Abdussalam al-Muntasib, Visi dan Paradigma Tafsir Al-Qur'an Kontemporer, 330.

${ }^{37}$ Muhammad Al-Ghozali, Berdialog dengan Al-Qur'an, Terj. Masykur Hakim dan Ubaidillah (Bandung: Mizan, 1996), 174-175.
} 
(i tibar), bukan untuk menjelaskannya secara mendalam dan menggali ilmu-ilmunya.

3. Penafsiran dengan corak ini memaksa penafsir untuk melakukan "lompatan yang jauh" dalam memaknai dan manfasirkan ayat Al-Qur'an dari makna luar (zhahir) ayat tersebut.

4. Tafsir 'ilmy menjerumuskan orang yang mendalaminya pada kesalahan dalam mengkompromikan dua istilah dari dua kutub yang berbeda (al-Qur'an dan ilmun pengetahuan sains)

5. Ilmu-ilmu yang tergali dalam penafsiran ini hanya bersifat sementara dan akan berubah ketika ada penemuan-penemuan baru yang lebih besar. Hal ini membuat al-Qur'an tidak bisa untuk menemukan pijakan sebagai sumber dari segala ilmu, karena terus berubah penafsirannya. ${ }^{38}$

Selain dua sikap ulama di atas, ada pula ulama kontemporer yang bersikap moderat, yang mencoba mencari jalan tengah di antara dua kubu yang berseberangan, yakni menerima dengan memberikan syarat tertentu, antara lain; Musthafa al-Maraghi (w. 1965 M), Sayyid Qutb (w. 1933 M), dan Nashir Makarim al-Syayraziy menerima tafsir 'ilmy namun dengan syarat bahwa teori sains yang diterapkan dalam al-Qur'an harus sudah mapan dan pasti. Menurut al-Maraghi "Kita tidak boleh menarik ayat-ayat al-Qur'an kepada ilmu sains, atau menghubungkan sains dalam menjelaskan fakta-fakta al-Qur'an. Akan tetapi, al-Qur'an dapat ditafsirkan dengan sains jika lahiriyah ayat sejalan dengan fakta-fakta yang pasti" 39

Termasuk pula Muhammad Qurais Shihab, dalam bukunya "Membumikan al-Qur'an" memberikan ketentuan tertentu. Pertama, penafsirannya sejalan dengan kaidah bahasa Arab.

\footnotetext{
${ }^{38}$ Tim Forum Karya Ilmiah RADEN (refleksi anak muda pesantren), Al-Qur'an Kitab Studi Ilmu, Sejarah dan Tafsir Kalamullah (Kediri: Lirboyo Press, 2011), 248-249.

${ }^{39}$ Abdul Mustaqim, 106.
}

Kedua, memperhatikan konteks antara kata atau ayat, baik ayat sebelumnya maupun ayat sesudahnya. Ketiga, berdasarkan pada fakta ilmiah yang telah mapan. Di samping itu, penemuan ilmiah tersebut tidak dapat diatasnamakan sebagai al-Qur'an. Al-Qur'an sebagai wahyu, kebenaran al-Qur'an diakui secara mutlak, sementara kebenaran temuan ilmiah bersifat relatif, maka jangan terjebak dalam trut claim. $^{40}$

Menurut kelompok moderat, tafsir 'ilmy dapat diterima dan diterapkan terhadap ayat-ayat al-Qur'an dengan catatan seorang mufasir memenuhi tiga syarat berikut ini, yaitu: ${ }^{41}$

a. Penafsirannya sejalan dengan kaidah kebahasaan. Disebabkan al-Qur'an diturunkan dalam bahasa Arab, maka ketika menafsirkan ayat-ayat ilmiah, seorang mufasir harus paham dengan kaidah-kaidah bahasa Arab. Selain mengerti dengan ilmu i'rab, bayan, ma'ani, dan badi', sesuai dengan kaidah-kaidah dalam kitabkitab tafsir dan kamus, seorang mufasir juga harus memperhatikan dan mempertimbangkan perkembangan arti dari suatu kata.

b. Memperhatikan korelasi ayat (munasabat alayat). Selain menguasai kaidah kebahasaan, seorang mufasir ilmi harus juga dituntut untuk memperhatikan korelasi ayat, baik ayat sebelumnya maupun ayat sesudahnya. Hal ini penting, mengingat penyusunan al-Qur'an tidak berdasarkan pada kronologi turun ayat, melainkan berdasarkan pada korelasi makna ayat-ayatnya, sehingga kandungan ayat sebelumnya senantiasa berkaitan dengan kandungan ayat yang berikutnya.

c. Berdasarkan pada fakta ilmiah yang telah mapan. Sebagaimana diketahui, sebagai kitab wahyu, kebenaran al-Qur'an diakui secara mutlak. Otentisitas dan validitasnya dapat diuji dari berbagai perspektif, baik dari perspektif sejarah, kebahasaan, berita ghaib,

\footnotetext{
${ }^{40}$ M. Quraish Shihab, 105-110.

${ }^{41} \mathrm{http}$ //suakakata. blogspot.com/2009/01/ debat-sekitartafsir-ilmiah.html.
} 
dan bahkan dari aspek ilmiah sekalipun. Oleh sebab itu, pensejajaran al-Qur'an dengan teoriteori ilmiah yang tidak mapan, tentu saja tidak dapat diterima. Dan, bila diperhatikan secara seksama, sesungguhnya menyandingkan ayatayat al-Qur'an yang memiliki kebenaran mutlak dengan kebenaran temuan ilmiah yang bersifat relatif, adalah salah satu alasan utama kelompok yang menolak penerapan tafsir 'ilmy terhadap al-Qur'an.

\section{Kesimpulan}

Adapun butir-butir pokok sebagai kesimpulan yang dapat dipetik dari pembahasan mengenai kontribusi tafsir ilmy terhadap penafsiran al-Qur'an yang telah dipaparkan di atas, bahwa tafsir 'ilmy adalah penafsiran dengan memakai pendekatan teori-teori ilmiah dan pemikiran-pemikiran filosofis sesuai dengan dinamika dan perkembangan zaman dari teks ayat-ayat al-Qur'an, di samping bertujuan membenarkan dan mengkompromikan teori-teori ilmu pengetahuan dengan al-Qur'an, juga bertujuan menggali ilmu pengetahuan dari ayatayat al-Qur'an.

Keberadaan tafsir 'ilmy mengundang sikap pro kontra di kalangan ulama, ada yang mendukung, ada pula yang menentang dan pula yang bersikap moderat. Bagi yang mendukung meyakini bahwa al-Qur' an memuat berbagai ilmu pengetahuan yang dapat digali darinya. Yang menentang berpendapat bahwa al-Qur'an bukanlah kitab ilmu pengetahuan, melainkan kitab petunjuk moral dan ibadah bagi umat manusia. Sementara bagi yang moderat memberikan persyaratan tertentu, sehingga tafsir 'ilmy tidak terlalu jauh melangkah dengan memaksakan teori-teori ilmiah ke dalam alQur'an. Di antara syarat-syaratnya adalah harus sejalan dengan kaidah bahasa Arab, memperhatikan konteks antara kata atau ayat maupun konteks sosial masyarakat Arab, dan berdasarkan pada fakta ilmiah yang telah mapan. Di samping itu, penemuan ilmiah tersebut tidak dapat diatasnamakan al-Qur'an melainkan sebagai bukti kemukjizatan al-Qur'an secara mutlak.

\section{Daftar Kepustakaan}

A. Mufakhir Muhammad. Tafsir 'Ilmi. Banda Aceh: Yayasan PeNA, 2004.

Al-'Aridl, Ali Hasan. Sejarah dan Metodologi Tafsir. Terj. Ahmad Akram. cet. II. Jakarta: PT. Raja Grafindo Persada, 1994.

al-Yassu'i, Louis Ma'luf dan Bernand Toffel alYassu'i. al-Munjid al-Wasith fi al'Arabiyyah al-Mu'ashirah. Beirut: Dar alMasyriq, 2003.

Adz-Dzahabi, Husain. Tafsir wa al-Mufassirun. Juz 2. Al-Qahirah: Maktabah Wahbah, 2000 .

Adz-Dzahabi, Muhammad Hussein. Al-Tafsir Wa Al-Mufassiruun. Vol. II. Kairo, Maktabah Wahbah, 2003.

Al-Ghozali. Ihya' 'Ulumuddin. Jilid I. Kairo: AlTsaqofah al-Islamiyah, $1356 \mathrm{H}$.

Al-Ghozali. Jawahir Al-Qur'an. Cet. 1. Mesir: Percetakan Kordistan, 1329 H.

Al-Ghozali, Muhammad. Berdialog dengan AlQur'an. Terj. Masykur Hakim dan Ubaidillah. Bandung: Mizan, 1996.

al-Muhtasib, Abd al-Majid Abd al-Salam. Ittijahat al-Tafsir al-Asr al-Hadits. Beirut: Dar alFikr, 1987.

al-Muntasib, Abdul Majid Abdussalam. Visi dan Paradigma Tafsir Al-Qur'an Kontemporer. terj. Mohammad Maghfur Wachid. Judul asli Ittijaahat at-Tafsiir fi al-Ashri ar-Rahin. Bangil: Al-Izzah, 1997.

al-Qattan, Manna' Khalil. Mabahits fi 'Ulumi alQur'an. Riyadh: Mansyuraat al-'Ashar alHadits, 1973. 
al-Rumi, Fahd bin Abdurrahman bin Sulaiman. Ittijahat al-Tafsir fi al-Qur'an al-Rabi' 'Asyar. Mamlakah al-'Arabiyyah alSu'udiyyah, 1997.

Al-Rumi, Fahd ibn Abdurrahman. Buhuts fi Ushul al-Tafsir wa Minhajuhu.(t.tp: Maktabah alTaubah, t.th.

Badri Yatim. Sejarah Peradaban Islam. Jakarta: Rajawali Pers, 2010.

Ghulsyani, Mahdi. Filsafat Sains Menurut alQur'an. Bandung: Mizan, 1994.

http://suakakata.blogspot.com/2009/01/debatsekitar-tafsir-ilmiah.html.

http://kbbi.web.id/indek.php/w=tafsir. Diakses tanggal 12 April 2015.

Jawhari, Thantowi. al-Jawahir fi Tafsir al-Qur'an al-Hakim. Juz I. T.tp.: Musthafa al-Halabi, T.th.

M. Quraish Shihab. Membumikan Al-Qur,an: Fungsi dan Peran Wahyu dalam Kehidupan Masyarakat. Cet. XIX. Bandung: Mizan, 1999.
Muhammad Amin Suma. Studi Ilmu-ilmu AlQur'an 2. Jakarta: Pustaka Firdaus, 2001.

Rahman, Afzalur. Qur'anic Sciences. London: The Muslim Schools Trust, 1981.

Rohimin. Metodologi Ilmu Tafsir dan Aplikasi Model Penafsiran. Yogyakarta: Pustaka Pelajar, 2007.

Said Agil Husein Al-Munawwar. Membangun Tradisi Kesalihan Hakiki. Jakarta: Ciputat Press, 2002.

Sayid Musa Husaini. "Metode Penafsiran Saintis di dalam Buku-buku Tafsir Modern"; diperoleh dari http://quran.al-shia.com/id/ metode/01.htm. di akses: 11 Oktober 2012.

Tim Forum Karya Ilmiah RADEN (refleksi anak muda pesantren). Al-Qur'an Kitab Studi Ilmu, Sejarah dan Tafsir Kalamullah. Kediri: Lirboyo Press, 2011.

Wildana Wargadinata. "Perkembangan Pemikiran Zaman Abbasiah Sebagai Akar Tafsir 'ilmy Abad Modern'. Dalam Jurnal elHarakah 9, No. 1 (2007), 24. 


\title{
UNDERSTANDING LEVEL OF TABLIGH JAMAAT MEMBERS AT AN-NAHL Verse 125 \\ (Case Study at Mosque of al-Falah II Jl. Sumatra Pekanbaru)
}

\author{
Jani Arni \\ Fakultas Ushuluddin UIN Suska Riau \\ Jani.Arni@uin-suska.ac.id
}

\begin{abstract}
This study studied the level of understanding of the Tabligh congregation members about the letter of al-Nahl verse 125 which contains about methods in preaching. Tabligh Jamaat is one group of Muslims who could be called active in proselytizing. They were proselytizing door to door or directly into the homes of Muslims to invite to goodness. Da'wah in the congregation sermons made by all members, because they think that the task of the mission is not only clerical duties. Al-Qur'an as a book of guidance has explained how the procedures or methods in carrying out da'wah. In Surat al-Nahl verse 125 explained that there are three methods of da'wah; bil hikmah, al-mau'izhah al-hasanah, and jadilhum billati hiya ahsan.From research conducted found that the level of understanding and practice of members of Tabligh congregation was very varied; some have a good understanding and practice, there are less in understanding the verses about methods of da'wah but its practices is good, as well as small part that have a poor understanding and its practice.
\end{abstract}

Keywords: The level of understanding, Tabligh Jamaat, and Da'wah

\section{Introduction}

Etymologically, da'wah implies to invite something and call to a problem. While in terminology it has meaning to spread and convey Islam with all its teachings. ${ }^{1}$ Al-Qur'an is often referred to as a book of da'wah, that al-Qur'an is the basic reference and authentic source of knowledge about $d a$ 'wah (propaganda). Sayyid Qutb explains al-Qur'an is a book of propaganda which has a plant spirit, and serves as an amplifier. Al-Qur'an serves as a guard, lights, explanatory, and legislation, as well as global concepts in da'wah. Moreover, the Koran is also the only place to return to the caller of propaganda in taking

1Lajnah Ilmiah bi Ma'had al-Aimmah wal Khutaba, Sirah Nabawiyah dan Dakwah (Jakarta: Wamy, 2004), 63-64. reference in proselytizing activities, as well as in developing a concept of the next missionary movement. $^{2}$

$D a$ 'wah is the command of Allah SWT in His words. Among the verses that command to perform the mission is:

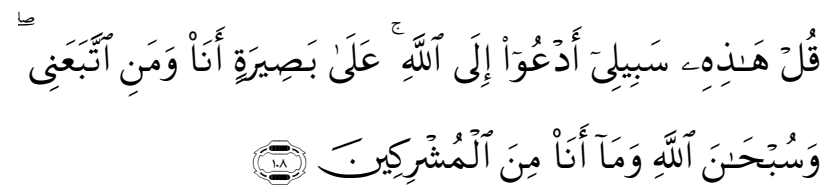

Say: "This is the (religious) me, me and the people who follow me invites (you) to God with real proof, Glory to God, and I'm not

\footnotetext{
${ }^{2}$ Asep Muhyiddin dan Agus Ahmad Safe'i, Metode Pengembangan Dakwah (Bandung: Pustaka Setia, 2002), 15; see, Sayyid Quthb, Fiqh Dakwah (Jakarta: Pustaka Amani, 1995), 1.
} 